Macedonian Pharmaceutical Bulletin, 66 (Suppl 1) 141 - 142 (2020)

Online ISSN 1857 - 8969

UDC: 615.33 .015

DOI: 10.33320/maced.pharm.bull.2020.66.03.070

Short communication

\title{
Formulation and evaluation of a solid self-emulsifying drug delivery system containing cefuroxime axetil
}

\author{
Eleonora Trajanovska ${ }^{1} *$, Frosina Jovanovic ${ }^{1}$, Ana Atanasova ${ }^{1}$, Maja Hadzieva Gigovska ${ }^{1}$, \\ Oja Ali Memed ${ }^{1}$, Packa Antovska ${ }^{1}$, Sonja Ugarkovic ${ }^{1}$, Marija Glavas Dodov ${ }^{2}$ \\ ${ }^{1}$ Research and Development, Alkaloid AD, Blvd. Aleksandar Makedonski 12, 1000 Skopje, North Macedonia \\ ${ }^{2}$ Faculty of Pharmacy, Ss. Cyril and Methodius University, Mother Theresa 47, 1000 Skopje, North Macedonia
}

\section{Introduction}

One of the biggest problems in formulation of oral pharmaceutical dosage forms is the lipophilic nature of the drug substances, therefore, various formulation strategies have been explored in recent years such as usage of lipid solutions, emulsions and emulsion concentrates prepared as physically stable formulations suitable for encapsulation of poorly soluble drugs (Rodriguez-Aller et al., 2015).

Formulation approaches, such as selfemulsifying drug delivery systems (SEDDS) have been recently used to overcome drug solubility problems (Vasconcelos et al., 2017) by using isotropic multi component system composed of oil, surfactant and co-surfactant/co-solvent, which form micro- or nano-emulsion in the presence of water.

Soft gelatine capsules are simple and commonly used dosage forms for encapsulation of liquid SEDDS, nevertheless, this technology have some limitations i.e. manufacturing and packaging process difficulties, stability of the final drug product, etc. Due to these reasons, attention has been focused on formulation of solid SEDDS in form of tablets (uncoated or film-coated tablets) (Joyce et al., 2018). In that direction, various formulation strategies have been used for solidification of SEDDS, among which the simplest approach is adsorption of the SEDDS to solid carriers-excipients, commonly used in tablet formulation (Mandić et al., 2017). The purpose of the study was formulation of a solid
SEDDS containing the poorly soluble cefuroxime axetil in a form of a conventional tablet.

\section{Materials and methods}

Cefuroxime axetil (CA) was supplied from Orhid Chem. Pharm. Ltd. (India). Olive oil, talc (Parteck $^{\circledR}$ Lub Talk Emprove), methanol and citric acid monohydrate were obtained from Merck KgaA, Germany. Microcrystalline cellulose (MCC-Avicel ${ }^{\circledR}$ PH 112) and croscarmellose sodium (CS-AcDiSol ${ }^{\circledR}$ ) were supplied from FMC Biopolymer, USA. Polyvinylpyrrolidone (PVP-Kollidon ${ }^{\circledR}$ 30F) and Polyvinylpyrrolidone, crosslinked (PVP-CKollidon ${ }^{\circledR}$ CL) were supplied from BTC Chem. Distrib., Germany. Polysorbate 80 (Tween 80) was obtained from Croda Europe Lim., France, polyethylene glycol (PEG 400) from Clariant, Germany, colloidal anhydrous silica (CAS-Aerosil ${ }^{\circledR}$ 200) from Pharma Evonik Ind., Germany, magnesium stearate (MS) from FaciSpA-Carasco GE, Italy and lactose monohydrate (LM-Tablettose ${ }^{\circledR}$ 100) from Meggle, Germany.

\section{Preparation of solid SEDDS granules and tablets}

CA was successfully incorporated in the mixture of olive oil, PEG 400, Tween 80 and citric acid monohydrate (data are not presented). Incorporation of the SEDDS onto solid drug carries was done using a high shear granulation technique (all samples

\footnotetext{
* etrajanovska@alkaloid.com.mk
} 
contained SEDDS 57\% and CAS 18\%; additionally, granules were prepared with: S1: MCC 13\%, PVP 2.2\%, PVP-CL 9\%; S2: MCC 13\%, PVP 2.2\%, CS 9\%; S3: LM 13\%, PVP 2.2\%, CS 9\% and S4: MCC $13 \%$, PVP-CL 9.5\%; impeller speed $400 \mathrm{rpm}$, chopper speed $1000 \mathrm{rpm}, 5 \mathrm{~min}$; Diosna P1/6, Diosna Dierks \& Söhne GmbH, Germany). Obtained granules (S1-4) were sieved (mesh size 18) and blended with the lubricant and glidant (Talc 0.5\%, MS 0.5\%; 25 rpm, 3 min; Erweka PM5, Erweka $\mathrm{GmbH}$, Germany). Flow properties of the final blends were evaluated according to Ph. Eur. 9.0 (2.9.36 and 2.2.32, respectively). Prepared granules were compressed into oblong, biconvex, white tablets with length of $21 \mathrm{~mm}$ on rotary tablet press (Korsch Pro XL100, Germany). The tablets were characterized for: mass and uniformity of mass (Ph. Eur. 9.0 (2.9.5); Sartorius Secura 224-1 CEU, Sartorius AG, Germany), hardness, diameter and thickness (Erweka Hardness Tester 425 TD, Erweka $\mathrm{GmbH}$, Germany), friability (Ph. Eur. 9.0 (2.9.7); Erweka TAR 100, Erweka GmbH, Germany) and disintegration (Ph. Eur. 9.0 (2.9.1); Erweka ZT322, Erweka $\mathrm{GmbH}$, Germany). Assay analyses of CA were done using the HPLC systems (Agilent 1200 Binary Series, DAD detector, Germany and Hitachi Elite $^{\circledR}$ Lachrom, Hitachi, USA), column (Inertsil ${ }^{\circledR}$

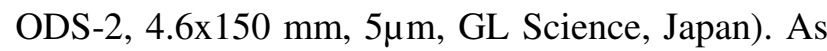
a mobile phase, $20 \%$ methanol and $80 \%$ water purified were used, with chromatographic conditions: mobile phase flow of $1 \mathrm{~mL} / \mathrm{min}$, column temperature of $40{ }^{\circ} \mathrm{C}$, injection volume of $100 \mu \mathrm{L}$ at $281 \mathrm{~nm}$. In vitro CA release from the tablets $(n=3)$ was carried out with USP Apparatus II using 900 $\mathrm{mL}, 0.07 \mathrm{~N} \mathrm{HCl}$ as dissolution media (Varian Vankel 7025 Model 115/230, Varian, USA) at $37 \pm 0.5{ }^{\circ} \mathrm{C}$ and $100 \mathrm{rpm}$. At predetermined time intervals (after 5, 10, 15, 20, 30 and $45 \mathrm{~min}$.), $10 \mathrm{~mL}$ were withdrawn and filtrated $(0.20 \mu \mathrm{m})$ and were and analyzed by above mentioned HPLC method.

\section{Results and discussion}

Prepared granules showed fair (S1-2) to good flow (S3-4) properties, considering the high oil loading in the formulations. Characterization of the physical properties of the tablets showed that all obtained results are within the predetermined acceptance criteria (tablets mass of $1100 \mathrm{mg} \pm 5 \%$ with $21 \pm 0.3$ and $6.5 \pm 0.2 \mathrm{~mm}$ for tablet diameter and thickness, respectively, 2-5 kP hardness, friability of $\max 1 \%$ and disintegration time of max. 15 min.

Determined CA content and the drug release studies from different tablets as solid SEDDS formulations showed that sample $S 3$ released $\sim 87 \%$ of CA during the period of $15 \mathrm{~min}$. and more that 96\% after 45 min. (99.6\% CA content), thus complying with the USP specification for conventional CA tablets. In comparison, the in vitro release of CA $(125 \mathrm{mg})$ as a powder was 8 and $13 \%$, respectively, in the same time intervals and under the same test conditions.

\section{Conclusion}

Conventional immediate release tablets containing SEDDS of CA were prepared using simple solidification with adsorption of the SEDDS onto solid carrier containing different excipients. Based on in vitro dissolution studies, selected sample will be further evaluated for formulation optimization.

\section{References}

European Pharmacopoeia 9th Edition (Ph. Eur. 9.0), Council of Europe, Strasbourg, France.

Joyce, P., Dening, T.J., Meola, T.R., Schultz, H.B., Holm, R., Thomas, N., Prestige, C.A., 2018. Solidification to improve the biopharmaceutical performance of SEDDS: Opportunities and challenges. Adv. Drug Deliv. Rev. 142, 102-117.

Mandić, J., Zvonar Pobirk, A., Vrečer, F., Gašperlin, M., 2017. Overview of solidification techniques for selfemulsifying drug delivery systems from industrial perspective. Int. J. Pharm. 533, 335-345.

Rodriguez-Aller, M., Guillarme, D., Veuthey, J., Gurny, R., 2015. Strategies for formulating and delivering poorly water-soluble drugs. J. Drug Deliv. Sci. Technol. 30, 342-351.

United States Pharmacopeia and National Formulary (USP 41-NF 36). Rockville, MD. United States Pharmacopeial Convention 2016.

Vasconcelos, T., Marques, S., Sarmento, B., 2017. Measuring the emulsification dynamics and stability of self-emulsifying drug delivery systems. Eur. J. Pharm. Biopharm. 123, 1-8.

Maced. Pharm. Bull. 66 (Suppl 1) 141 - 142 (2020) 